\title{
PROGRAMMING CONTENT AND QUALITY
}

\author{
ROGER KENNEDY*
}

To its creator, a television or radio program may seem a work of art. To a station, or a network, it is a commodity to be sold, existing not so much for its own value, but so that the time it occupies may be sold and adjacent blocs of time may rise in market value. To the advertising agency, it is a camouflage or carrier of commercials which seek to induce and direct spending. To the "talent" it presents, it is a forum, or a stage, or a market. And to the Federal Communications Commission, it should be a contribution to the public interest, convenience, and necessity. ${ }^{1}$

I will try to picture the spawning ground of these programs, the way in which their content and quality are affected by federal and private regulation and influence, how their value is gauged, and then conclude with some suggestions for their improvement.

Since television is an infinitely more important factor in our economic and cultural life than radio is or ever was, it is of television that I will speak the more. ${ }^{2}$

\section{Influences on Programming}

Who makes television programs? The average television station, affiliated with a network, produces less than ten per cent of the programs it carries. Local advertising agencies and packagers (independent producers who sell an idea to an agency, client, or station, and then retain control of its talent, material, and management) may contribute another ten per cent. The rest comes in by relay or cable from the network. While there remains, theoretically, the right of any station to purchase a network program which the network's usual affiliate station rejects, it almost never is exercised: there is, for each station, only "the" network. But only half of the network programs actually are born in the network studios; nearly all the others come from national advertising agencies or packagers. In the days when radio reigned alone, that was not so; nearly all the network programs were agency-produced, and the network served primarily as a broker of its stations' time. 'Today, however, the advertiser often engages an independent producer to "package" a series, and the advertising agency serves merely to "buy time" on a station or on a network, which then, through its "Station Relations Department," books the time with its affiliates." Church groups

- B.A. 1949, Yale University; LL.B. 1952, University of Minnesota. Formerly United States Department of Justice lawyer and Special Assistant to the Secretary of Health, Education, and Welfare; Washington correspondent for the National Broadcasting Company; as Project Manager for NBC's Project 20, charged with sales of NBC's Public Affairs programming.

148 STAT. 1082 (I934), as amended, 47 U.S.C. $\$ 303$ (I952).

2 But radio, however, is by no means dead. See Anybody Listening? Time, Dec. 2I, I953, p. 42.

"An example of "packager production" is The $\$ 64,000$ Question, which originated in the library of Louis Cowan, a packager, who sold the idea to an advertiser, Revlon, and its agencies and to the CBS network. 
and labor unions may also create programs and buy network or local time for them. Prime examples are programs featuring commentators like John W. Vandercook and Edward P. Morgan, whose primary responsibility is to the AFL-CIO, rather than to $A B C$, and Sunday programs produced largely by Catholic, Jewish, Lutheran, and evangelical groups. Farm groups and business associations, like the Chamber of Commerce and the National Association of Manufacturers, have strangely failed to follow in the direction of sponsor-packaging.

The influence of private groups, however, is largely used to smother, not to conceive or foster programs. Networks and stations are concerned far more with their reaction to programs than with the attitudes of federal agencies. Some movies are not shown on television, some characters excised, some motivations discouraged, and some stories not selected from scripts submitted to dramatic shows because they might offend these potent amateur censors. Though their content may seem innocent, some never reach the audience because quiet caution calls their authors dangerous. Some news stories are gingerly handled, their true importance veiled, because it seems safer so. A race riot may be called a "teen-age gang fight," and no pictures shown, because racial groups may be affronted. Stations and networks are naturally cautious, but advertisers and agencies are even more so, because they fear the subtle effect of a group's disapproval upon sales; and unlike stations, they feel not even the very feeble affirmative force of the FCC's exhortation to behave in the public interest.

It is easier to find the marks of caution's strangling hand upon the throat of programs of fact, but there is an equally deadly influence working upon television drama. Advertising agencies and clients vary in their willingness to permit freedom to writers, producers, and performers. BBDO and the United States Steel Company have for some years permitted great freedom in the subject matter of their programs. Producers like Martin Manulis, Fred Coe, Worthington Minor, and Delbert Mann have liberated some small areas of drama from the thrall of caution and cant. But daring, imagination, innovation, and vigor seldom swirl the surface of this pool of torpor. Why? Because nothing hurts nothing.

The point is this: unlike movies or theater, television offers an invitation to imagination because each program has already been bought before it appears. The time has been purchased, the producing company and talent hired, the budget committed, before the script is known. It is not necessary to "sell" the script to distributors or even the public. The audience is there, waiting in the living room. So when they are presented with pap, night after night, they are being needlessly cheated. When better programs are offered, their ratings sky-rocket, as NBC's Nightmare in Red and Twisted Cross greatly increased the customary listenership of the period in which they appeared. Greater "producer control," insulated by purposeful network protection from agency and client interference, is a necessity. Lately, there have been some hopeful signs.

The networks themselves have taken much more active control of production and 
program development. NBC's "magazine concept" programs, Today and Tonight, are network produced and account for nearly one-third of "network time." According to CBS, seven of its eleven basic programs are network-produced. NBC's Monitor, which now runs on radio from Friday evening through midnight Sunday, is a "network program" in origin and control. Like the three television magazine shows, Monitor is not broken into blocks to be purchased wholly by a single advertiser, but is supported by commercial "inserts," as a magazine or newspaper depends upon space sold to advertisers and inlaid among the news.

This tendency toward network control was, in part, a tribute to the personal force of certain network executives (of whom Sylvester L. Weaver is the best known) who sought powers previously exercised by agency executives, and, in part, a response to high demand. Prosperity poured its surplus into advertising budgets, network time was largely sold out, and sponsors were happy to buy what they could, on the network or station's terms. Now, unfortunately, when there is less to spend, there will be more time unsold, more agency control, and programming will move farther away from the admittedly feeble influence of the FCC.

And control is important, because the interests of agencies, networks, stations, producers and the public all differ, and control means molding according to interest. In turn, the way programming is molded is important because American television. is not merely a means of communication; it is the most powerful single force shaping our civilization. More people spend more time watching television than earningwages." Advertisers spend more money for television than for any other medium, according to the largest agencies and the network's research departments. The television industry presents a scene of constant change and motion, the products of its incredible fecundity nourished by a compost-heap of failure.

\section{II}

\section{The Federal Communications Commission}

This is the scene before the eyes of the Federal Communications Commissioners. It is their kingdom! How are they equipped to order and orient all this toward the public interest? Unfortunately, throughout its history, the FCC has been too poorly equipped, too hesitant, deferential, or indifferent to assume new functions as new responsibilities arose.

In Igro, Congress recognized that Marconi's wireless could be used to safeguard navigation and decreed that all vessels carrying $5^{\circ}$ passengers or more should be radio-equipped. 5 The Secretary of Commerce was to see to the matter, and two years later he was asked, rather diffidently, to keep an eye on the hundreds of tiny radio transmitters putting up feeble signals across the land, as an automatic sprinkling system spreads out across the lawn. ${ }^{6}$

'Sce research statistics cited by Martin Mayer, Television's Lords of Creation, Part I: Strategic Thinking at NBC, Harper's Magazine, Nov. 1956, p. 25.

- Wireless Ship Act of June 24, 1910, 36 STAr. 629, 46 U.S.C. $\$ 484$ (I952).

- Radio Act of Aug. I3, 1912, 37 Stat. 302; repealed, Radio Act of Feb. 23, 1927,-44 Stat. ir62. 
But the Secretary lost control completely after the courts and the Attorney General interpreted his authority so narrowly that he could not do other than issue licenses to any applicant. ${ }^{7}$ The sprinklers became geysers and inundated each other with discordant sound. The Secretary cried out to the President, and the President to Congress, and, finally, the Radio Act of 1927 was passed to quiet and order the babble. ${ }^{8}$ The limited number of frequencies which AM receivers could receive had been allocated by the Secretary of Commerce so that the dialer heard but one voice at a time: from $55^{\circ}$ to 1500 kilocycles, there were 96 channels with a Io $\mathrm{KC}$ hedge between neighbors. Now the allocation was policed. The FCC went to work shutting down many transmitters and issuing licenses. Its first duties, thus, were negative. It remedied a disorder which had become a considerable public inconvenience. Then, to the dismay of some, it became necessary to give the Commission power to strangle any voice it did not license and to bestow a glittering largesse on those it favored. Commercial radio was young, but it was vigorous, and it was already clear that an FCC license was worth money. Yet, the Commission's limited view of its own responsibility lessened both the danger of tyranny and the possibility of an influence thrusting toward the good.

As we have seen, through its licensing power, the Commission controls the retailer of programs-the station itself. At the same time, it can less directly affect the networks by controlling the arrangements which stations can make with networks and because each network has a number of "owned and operated" stations. These stations account for a substantial part of network revenue and are the guarantors of the networks' ability to deliver to advertisers the time of stations covering major metropolitan areas. An FCC threat to withdraw licenses from these stations, even if all networks were similarly treated, is a threat to networks as grave as to a tree threatened that its branches would be lopped off.

When, in 1941, the FCC issued its "chain-broadcasting regulations," it lifted the networks with the second lever, their contractual relations with their affiliated, but not owned, stations. By stating that a station might lose its license if it lived in sin with the network, the FCC could effectively force the stations and networks to have their assignations quietly, privately, and without publicly shocking the sensibilities of congressmen.

Regulation of contracts between stations and networks has a strong effect upon the distribution of industry's profits and, to a lesser extent, on programming. For these regulations could control the amount of time the stations and networks allocate for commercials, which are, after all, part of programming. Contrary to widespread public misapprehension, no such regulations have been issued by the Commission, though "the Code" has been issued by the National Association of Radio and Television Broadcasters, stating proportions of commercial to "program" material which

${ }^{7}$ Hoover v. Intercity Radio Co., 286 Fed. 1003 (D.C. Cir. 1923); United States v. Zenith Radio Corp., I2 F.2d 614 (N.D. Ill. 1926); 35 OPs. ATr'y GEN. 126 (1929).

${ }_{44}$ Stat. I 162 c. I69, $\$$ I. 
might show becoming self-restraint. "The Code" is ignored by nearly all radio stations, but television stations tend to defer somewhat more to its guidelines, because there is always the black, hovering thought that the FCC might sometime start issuing regulations "unless the industry polices itself," and because the regulating force of public opinion constantly militates against "over-commercialization." Ratings can be weighed down when a schedule is too heavy on "commercials."

The FCC is largely a licensing body, rather than a regulating body. Though renewal of a license is generally a matter of the most untroubled routine, there are good reasons for owners to seek to impress the Commission, and why a "citation," or warning, arouses terror. Ownership of stations is becoming concentrated in fewer and fewer hands. The FCC, of late, has said it intended to issue more new licenses in previously uncovered areas. Possessors of existing licenses are coming to exert themselves to please the commissioners not because they fear that they may lose present provinces, but because they seek to extend their sway. So each, like an ambitious satrap, seeks to convince the Commission of the beneficence of its stewardship. The FCC receives from every applicant for a new license or a renewal elaborate statistical schedules and glowing descriptions of past performance and future plans. These plans are produced cynically, almost whimsically, by some applicants; if licenses were revoked for failure to build according to these glorious blueprints, the public would immediately be dazzled with the wonders the industry can perform. This would be the greatest single action the Commission could take in creating better programs: merely holding applicants to their promises. It is the sorry fact that its actual acquaintance or concern with the quality of programming is almost nonexistent. It can tell at a librarian's riffle how many public-service programs dealing, say, with agriculture, were carried by any station; but whether they were wellproduced or dowdy throwaways, the Commission does not know. It can judge programming only through the reports of time-use and brag-sheets submitted by stations, and through its own monitoring (listening-in), which is largely restricted to checking whether the time-use alleged is a true summary: whether the program was, indeed, classifiable under the claimed category, e.g., "discussion," "agriculture," "religious," or "educational." And, when it is all done, however well or ill, licenses are always renewed anyway, except when management has acted scandalously or so wildly that the Commission has no choice.

The public judges program quality differently: by its popularity and by its merit, qualities measured by "ratings" and by the consensus of published critics. The televiewer does not classify Twenty-One or The \$64,0oo Question with Omnibus or Art Linkletter's Houseparty. But the Commission, torpid and theoretical, takes no notice whatever that $60,000,000$ Americans endorse by their presence one program and ignore another. Similarly, a station receives from them no greater credit for Nightmare in Red or for Out of Darkness than for The Lawrence Welk Show or December Bride. Though all the critics may rate a program as a tasteless, squalid 
flop, the Commission clocks it equally with Richard III. It is time-use that impresses the FCC, not quality, nor popularity.

But networks, stations, and agencies must be impressed with popularity registered in ratings. Ratings are reports of surveys by independent companies employing a variety of diaries, interviews, telephone calls, and tattling gadgets attached to sets. Occasionally, they produce sharply different reports, but generally they show congruent patterns of listenership. They determine what the public will see, because they tell fairly accurately what the public wants to see. All producers know that however successful they may be in mesmerizing agencies, networks, or stations, programs generally go off the air unless they get a rating.

The television industry depends not only upon ratings, however, but upon a subtler pressure toward good programming: the pride of craftsmanship of the men who actually make programs. Craftsmanship, of course, cannot be regulated; it cannot be coerced; but, happily, it often pays. It also has been found that many programs which are in the public interest also interest the public, so, for sound business reasons, the quality of programming is improving, an improvement which owes nothing to the FCC. Does this mean that it should continue to reassure itself that statistical surveys are a form of regulation, should it retire entirely from regulation of programming? I think not. Some artificial stimulants must be used, to enlarge the area now consigned to programs which all admit to be important, to serve the public interest, convenience, etc., but which cannot compete with comedy and variety and drama for a crowd or ratings, particularly public-affairs programs.

Public affairs, or nonfiction programming, can be categorized frankly as a luxury. The FCC asks that these programs be carried, but it has done nothing to see that they are good. It could employ economic weapons to improve their quality and their access to an audience. First, it could improve them by requiring each station to carry (and prohibit contractual relations with networks which do not offer) such programs for a fixed number of hours during prime evening time (8-II P.M. EST). Since bad, sloppily-produced, and unimaginative programs will attract fewer viewers than better ones, each station and network will perforce improve the quality of these programs because of its regard for "lead-in" ratings." Though the market is colder, though advertising dollars are harder to find these days, there are still enough viewers watching the worst or most unpopular program to keep the advertisers' cost-per-thousand (price of time and program divided by thousands of viewers as estimated by the rating services) at a reasonably low level. Therefore, despite a chorus of grumbling, it is probable that such programs might sell for enough to return a profit to the network, station, agency, packager, advertiser, talent, and even at the end, abstractly, to the public.

The sponsorship of public-affairs programming raises a specter which apparently hovers persistently over the Commission; the apparition of a prophet, garbed in

\footnotetext{
"It is assumed that many listeners will stay to watch succeeding programs, once snared; a "dog" or sturkey" will cut the number of those who will watch the rest of a night's offering.
} 
coarsest burlap, with the sunken cheeks and the abstracted gaze associated with righteous poverty. This is what a good Vice President for Public Affairs Programming should look like, according to an institutional myth of the Commission, as it presents itself in a mystical devotion to sustaining programs. "Sustaining" means unsponsored, free from all commercial taint, and free, too, of the budget which only sponsors are able to contribute.

The Commission insists not that programs be good, as we have seen, but that program schedules carry a reasonable proportion of sustaining programs. This quaint but constricting suggestion infuriates all those who recognize that one very good way to insure better public-affairs programs is to spend more money on them. At the same time, it builds at each network a cloistered preserve in which earnest seminarians labor to fill time with programs of such dullness that the public has come to associate public affairs with boredom. Is this a healthy attitude to encourage? But it is encouraged by the FCC's preference for poverty. I submit that it is not in the public interest to regard lack of sponsorship as a virtue.

\section{III}

\section{Proposals for Better Programming}

A realistic appraisal of the effect of economics on programming requires examination of two proposals often advanced in the interest of broad economic objectives. First, it is suggested that under familiar Sherman Act principles, the "owned and operated" stations be separated from the networks. This might be done by an antitrust prosecution punishing a particularly predatory network practice or by an exercise to that end of the licensing power of the FCC. The Commission has long talked of its duty to bear in mind the objectives of the Sherman Act in exercising its licensing power, and now is looking into this possible application, ${ }^{10}$ especially in view of the recent Westinghouse-NBC litigation.

Viewed narrowly as an influence upon programming, I believe that such action would do more harm than good. If the " $O$ \& $O$ " stations are lopped from networks, any FCC regulation of program content would be less effective, because one degree removed from the largest manufacturers-the networks. A desire to retain these licenses now leads the networks to offer programs to these stations and, incidentally, all affiliated stations, which serve the public interest and which might not be offered if the $\mathrm{O} \& \mathrm{O}$ stations did not demand such efforts. ${ }^{11}$ Similarly, the revenue received from these lucrative sources constitutes much of the gravy ladled by networks into expensive and praiseworthy programming they could not otherwise afford. A court decree which made the networks poorer would probably make programming and the public poorer too.

\footnotetext{
${ }^{10}$ For history, see Note, 59 Yale L. J. 1342, I397-48 (I950); see also FCC, Report on Chain Broadcasting (I941); Comment, 66 Yale L. J. 365 (1957); FCC, Network Broadcasting, Report of the Network Study Staff to the Network Study Commttee (1957).

${ }^{11}$ Of late, NBC has offered its " $O \& O$ " stations only special programming, thus eroding this argument against severance of stations from network ownership.
} 
Second, there are those who seek an affirmative diversification of ownership, who would not only divorce the networks from the $\mathrm{O} \&$ O's, but would smash the crystals made up of a number of stations under common but not network ownership. ${ }^{12}$ But asking the FCC to prefer single independents to experienced groups already owning a number of stations asks, too, that experience be ignored in the difficult business of making programs. A neophyte might make this up by originality and sprightliness, but, in fact, the most distinguished programming has, in the past, consistently come from chain-operators like the Westinghouse stations and the CBS and NBC O \& O's. Some newspaper owners, like the Cowles, have a proud tradition to sustain, and they do not view responsibility as lightly as some more recent chainoperators. Management knows craftsmanship, too. A public gain in diversity would probably mean a public loss in quality.

There are, on the other hand, two proposals which have broad support and which, I think, would lead to far better programming:

First, the FCC should issue and enforce regulations which apportion "commercial" to program time. This, in turn, requires a warning to all stations that they will face inexorable justice on licensing day if they break these rules. Any listener in any metropolitan center now knows that the Commission's finger-wagging and the industry's recurrent homilies are mere ritual, without substance or purpose. The public would benefit from substituting control of a real evil (too many spots) for the deleterious and unrealistic dichotomy between public service and commercially sponsored programs. ${ }^{13}$

Second, and more important, is the proposal discussed at considerable length above, that applicants for broadcasting licenses be held to their word, be forced to perform their promises. The FCC cannot be expected to create programs itself. It cannot even patrol the industry to prod the producers into better production. But it can demand that its dignity be not so regularly and callously flouted by applicants filing statements of intention which they do not mean. Many broadcasting executives, embarrassed by their brethren, would welcome a statement in clear words from the Commission that it will no longer treat the honest and the contemptuous alike. The results, I think, would be marvelous to see. What wonders can a few words work in the world when they come from a tough cop.

${ }^{13}$ See, e.g., Comment, 66 Yale L. J. 365 ff. (1957); Clarksburg Pub. Co. v. FCC, 225 F.2d 511 (D.C. Cir. 1955).

${ }^{13}$ See discussion of public affairs and the piety of poverty, supra pp. 546-47. 